\title{
Leontiasis ossea; a rare presentation of secondary hyperparathyroidism
}

\author{
Hoda Raffiei Jelodar $^{\circledR}$, Maliheh Yarmohamadi $^{2^{*}}$, Massoud Baghai Wadji ${ }^{3}$, Mohammad Reza Babaei ${ }^{4}$ \\ ${ }^{1}$ Shahid Rajaei Cardiovascular, Medical and Research Center, Iran University of Medical Sciences, Tehran, Iran \\ ${ }^{2}$ Department of Internal Medicine, Kousar Hospital, Semnan University of Medical Sciences, Semnan, Iran \\ ${ }^{3}$ Department of Surgery, Firouzgar Hospital, Iran University of Medical Sciences, Tehran, Iran \\ ${ }^{4}$ Department of Interventional Radiology, Firouzgar Hospital, Iran University of Medical Sciences, Tehran, Iran
}

\section{A R T I C L E I N F O}

Article Type:

Case Report

\section{Article History:}

Received: 8 March 2018

Accepted: 20 July 2018

Published online: 9 August 2018

\section{Keywords:}

Renal osteodystrophy, Leontiasis ossea, Hyperparathyroidism, Intact parathyroid hormone, chronic kidney disease

\begin{abstract}
A B S T R A C T
Leontiasis ossea is a rare presentation of renal osteodystrophy with few reports in literature. It causes severe skeletal deformity in the cranial bones. This study presents a report on a patient with advanced hyperparathyroidism with skeletal changes compatible with leontiasis ossea. The patient was a 34-year-old man with end-stage renal disease, uncontrolled hypertension, and dyspnea who was referred to our hospital. Physical examinations revealed: toggled speech (nasal speech), mouth breathing and facial change, saddle nose, nares widening, increased interdental space and mandibular enlargement. His serum intact parathyroid hormone (iPTH) level was $3199 \mathrm{pg} / \mathrm{mL}$, Paranasal sinuses CT scan showed a significant expansion of the mandibular, maxillary and skull bones. Parathyroid sonography reported two severe hypertrophied parathyroid glands. The patient underwent total parathyroidectomy as a result of symptomatic bone involvement.
\end{abstract}

Implication for health policy/practice/research/medical education:

Uremic leontiasis ossea (ULO) can cause life-threatening upper airway obstruction and compressive cranial neuropathy. Hence, early recognition and treatment of leontiasis ossea can prevent its complications.

Please cite this paper as: Raffiei Jelodar H, Yarmohamadi M, Baghai Wadji M, Babaei MR. Leontiasis ossea; a rare presentation of secondary hyperparathyroidism. J Renal Inj Prev. 2018;7(4):321-323. DOI: 10.15171/jrip.2018.69.

\section{Introduction}

Renal osteodystrophy or chronic kidney disease-mineral and bone disorder is a bone pathology, caused by electrolyte and endocrine derangements in chronic kidney disease (1). There will be increase in phosphate and fibroblast growth factor 23, when glomerular filtration rate decreases below $60 \mathrm{cc} / \mathrm{min}$, then hyperparathyroidism, which causes the formation and resorption of renal osteodystrophy, will occur (2). Uremic leontiasis ossea (ULO) is the extreme presentation of renal osteodystrophy. This term was first used in leprosy. This descriptive term can be applied to changes in the facial bones with bilateral expansion of the malar processes and reduction of the nasomaxillary angle. Fibrous dysplasia, acromegaly, Paget's disease, McCune-Albright syndrome and kidney osteodystrophy can present with these facial changes (3). In the last decades with better phosphate control, increased dialysis quality and the administration of new medications, which suppress the high parathyroid hormone level, ULO is a rare presentation. Here, we report a patient with severe hyperparathyroidism and facial appearance compatible with leontiasis ossea.

\section{Case Presentation}

A 34-year-old Afghan man with history of the maintenance of hemodialysis for eight years, was referred to our center with uncontrolled hypertension and dyspnea. He complained of toggled speech, oral breathing, and severe headache. Four months ago, he noticed nose deformity, widening of interdental space, as well as enlargement of the maxillary and mandibular bones. In the last two months, he also complained of hearing loss. He had an episode of left femoral bone fracture, and right knee deformity that resulted to severe disability. On examination, he had saddle nose deformity, widening of the nares, hard palate hypertrophy, increasing interdental space (Figures 1A 


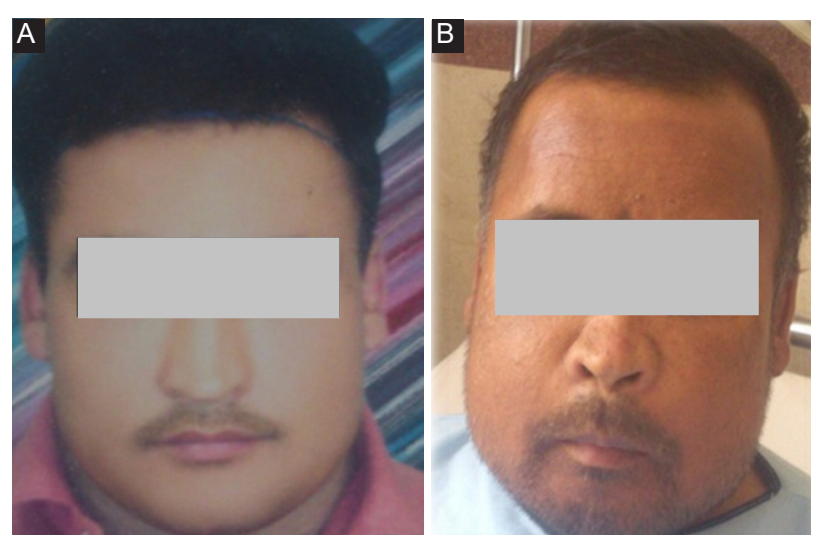

Figure 1. (A) Previous photo of patient at time of initiation of dialysis eight years before referring to the hospital. (B) Hypertrophy of maxillary with flattening nasal that looked like 'lion face'.

and $1 \mathrm{~B})$. The result of serum intact parathyroid hormone (iPTH) was $3199 \mathrm{pg} / \mathrm{mL}$ and serum calcium, albumin, and alkaline phosphatase were $10.5 \mathrm{mg} / \mathrm{dL}, 3.3 \mathrm{~g} / \mathrm{L}$ and 1200 $\mathrm{IU} / \mathrm{L}$, respectively.

Computed tomography scan of the paranasal sinus showed a significant expansion of mandibular, maxillary and skull bone with multifocal lytic lesions and bone cortical thickening with pharyngeal soft tissue hypertrophy. There were two well- defined masses (brown tumor) in the maxillary sinus with calcified rim and ethmoidal sinus mucosal hypertrophy (Figures 2A and 2B). Parathyroid ultrasonography showed two severe hypertrophied parathyroid glands with a coarse calcified pattern (the right parathyroid gland was $33 \times 25 \mathrm{~mm}$ and the left was $28 \times 20$ $\mathrm{mm}$ ). On bone densitometry, the T score of the lumbar and femoral bones were -5.84 and -3.24 , consequently compatible with osteoporosis. Parathyroidectomy was conducted due to severe symptomatic renal osteodystrophy and a high level of iPTH and parathyroid glands adenoma. In three months follow-up, there was improvement in his blood pressure, hearing and breathing. The patient had the opportunity to walk again.

\section{Discussion}

In advanced renal failure, increased secretion of parathyroid hormone is the result of gland hyperplasia, as well as reduced expression of calcium-sensing receptors. It causes decreased response to calcium level, hence secretion of the intact parathyroid hormone (iPTH) increases, despite the normal or high calcium level, which finally results to parathyroid autonomy $(4,5)$. Although parathyroid autonomy is frequently asymptomatic, this disorder can cause weakness, fractures, bone and muscle pain, as well as avascular necrosis (6). There are several forms of renal osteodystrophy, including osteitis fibrosa cystica, a dynamic bone disease, osteomalacia and mixed osteodystrophy (7). Leontiasis ossea is an uncommon presentation of renal osteodystrophy. It causes foraminal stenosis in the skull base, leads to upper airway obstruction
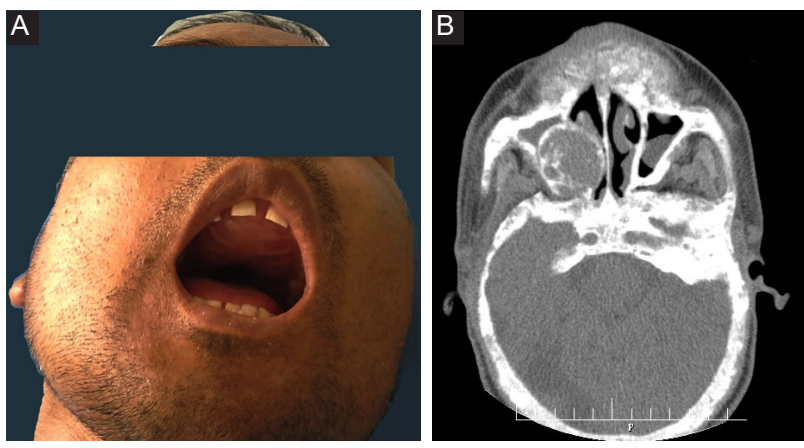

Figure 2. (A) Splaying of the teeth and hard palate hypertrophy. (B) Axial CT showing right maxillary sinus opacification, with cortical bone expansion and extending into the right nasal cavity.

or cranial nerve compressions such as facial palsy or hearing loss (8-10). In typical presentations, clinical and laboratory data which may facilitate the diagnosis and biopsy is rarely necessary. The present patient presented with aspects similar to Paget's disease and fibrous dysplasia of the bone (3).

In our patient, clinical manifestations such as symmetric cranial deformity, upper airway obstruction and widespread diffuse facial bony involvement with the laboratory and radiographic results, reinforced the diagnosis of severe renal osteodystrophy compatible with leontiasis ossea, that is a rare presentation of severe renal osteodystrophy due to secondary hyperparathyroidism. From 1988 to 2012, there have been eight patients of leontiasis ossea published in the literature, representing the rarity of the disease. However, the spectrum of skeletal sequelae from hyperparathyroidism has been classified under different names; thus it is difficult to know the exact number of reported cases (3).

Recently, as a result of the introduction of calcimimetics, phosphate binders, and active forms of vitamin $\mathrm{D}$, severe cases of hyperparathyroidism are rare. Our patient had a long-lasting history of uremia and uncontrolled mineral metabolism due to noncompliance so presented with severe hyperparathyroidism.

\section{Conclusion}

ULO may result in life-threatening upper airway obstruction and compressive cranial neuropathy. Early recognition and management of factors responsible for bone metabolism in chronic kidney disease can prevent its complications.

\section{Authors' contribution}

MY and MB managed the patient and prepared the manuscript. MY finalized the paper. All authors read and signed the final manuscript.

\section{Ethical considerations}

Ethical issues (including plagiarism, data fabrication, double publication) have been completely observed by 
the authors. The patient has given his informed consent regarding publication of this case report.

Conflicts of interest

There were no points of conflicts.

\section{Funding/Support}

None.

\section{References}

1. Tally Naveh-Many, Justin Silver, Henry M. Kronenberg. Parathyroid hormone: Molecular biology and regulation. In: Bilezikian JP, Raisz LG, Rodan GA, eds. Principles of Bone Biology. San Diego, California, USA: Academic Press; 2008:577-93.

2. Bargman JM, Skorecki K. Chronic Kidney Diseases. In: Longo DL, Kasper DL et al, eds. Harrison's Principles of Internal Medicine. 19th ed. New York, USA: McGraw-Hill; 2015:1811-21.

3. Collum J, Jones RH, Lynham A, Hirst J. Leontiasis ossea: a presentation of hyperparathyroidism in an indigenous Australian man secondary to chronic renal failure. J Oral Maxillofac Surg. 2013;71:56-61. doi: 10.1016/j. joms.2012.04.008.

4. Yano S, Sugimoto T, Tsukamoto T, Chihara K, Kobayashi A, Kitazawa S, et al. Association of decreased calcium-sensing receptor expression with proliferation of parathyroid cells in secondary hyperparathyroidism. Kidney Int. 2000;58:19806. doi: 10.1111/j.1523-1755.2000.00370.x

5. Cañadillas S, Canalejo A, Santamaría R, Rodríguez ME, Estepa JC, Martín-Malo A, et al. Calcium-sensing receptor expression and parathyroid hormone secretion in hyperplastic parathyroid glands from humans. J Am Soc Nephrol. 2005;16:2190-7. doi:10.1681/ASN.2004080657

6. Alvarez-Ude F, Feest TG, Ward MK, Pierides AM, Ellis HA, Peart M, et al. Hemodialysis bone disease: correlation between clinical, histologic, and other findings. Kidney Int. 1978;14:68-73.

7. Malluche HH1, Mawad HW, Monier-Faugere MC. Renal osteodystrophy in the first decade of the new millennium: analysis of 630 bone biopsies in black and white patients. J Bone Miner Res. 2011;26:1368-76. doi: 0.1002/jbmr.309.

8. Abid F1, Lalani I, Zakaria A, Facchini SA, Hunter JV. Cranial nerve palsies in renal osteodystrophy. Pediatr Neurol. 2007;36:64-5. doi:10.1016/j.pediatrneurol.2006.07.009

9. Dentz ME, Lubarsky DA. Leontiasis ossea: an unusual presentation of a difficult airway. Anesth Analg. 1993;76:678-9.

10. Schmidt RH, Rietz LA, Patel BC, Osborne AG, Pratt D, Digre KB. Compressive optic neuropathy caused by renal osteodystrophy. Case report. J Neurosurg. 2001;95:704-9, doi:10.3171/jns.2001.95.4.0704

Copyright (c) 2018 The Author(s); Published by Nickan Research Institute. This is an open-access article distributed under the terms of the Creative Commons Attribution License (http://creativecommons.org/licenses/by/4.0), which permits unrestricted use, distribution, and reproduction in any medium, provided the original work is properly cited. 